\title{
Thermal Effects on the Body mass, Transpiration rate, Feeding and Food Conversion of the Pillbug Armadillo officinalis (Isopoda, Oniscidea) Fed on the Dry Leaf of Punica Granatum
}

\author{
Abdelgader K. Youssef and G. Achuthan Nair
}

Department of Zoology, Faculty of Science, University of Garyounis, P. O. Box 9480, Benghazi, Libya, Email: gachuthannair@yahoo.com.

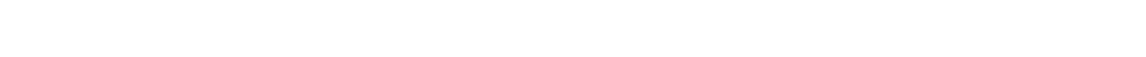

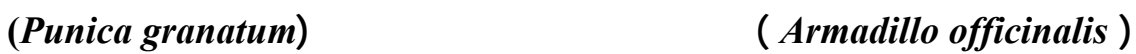

\section{عبدالقالر يوسف وأكوتلن نالير}

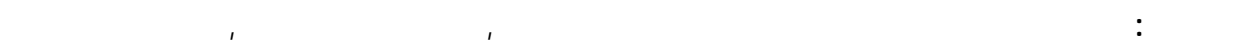

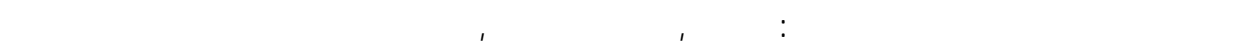

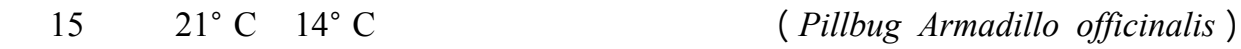

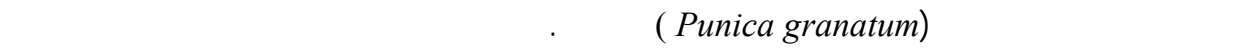

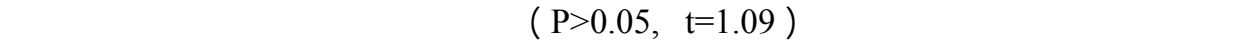

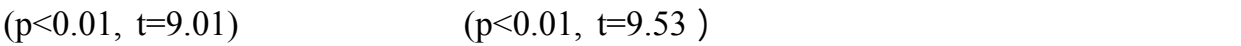
كفاية التمثل الغذائي (p< (p<0.05, t=2.58)

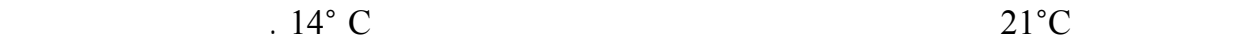
( Assimilated food)

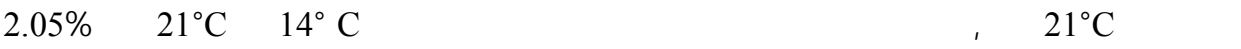

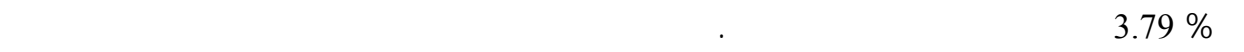

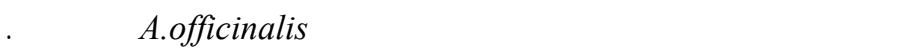

ABSTRACT: Observations were made on the body mass; transpiration rate; assimilation efficiency; gross and net production efficiencies; feeding, assimilation, conversion and metabolic rates of the pillbug Armadillo officinalis Dumeril acclimatized at $14^{\circ}$ and $21{ }^{\circ} \mathrm{C}$ for 15 days and fed on the dry leaf of Punica granatum (Pomegranate). 
A brief description is given on the chemical composition of $P$. granatum leaf. The difference in body mass increments of $A$. officinalis between the acclimatized temperatures was not significant $(\mathrm{t}=1.09 ; \mathrm{p}>0.05)$. However, significant differences were discernible on the transpiration rate $(\mathrm{t}=9.53 ; \mathrm{p}<0.01)$, moisture $(\mathrm{t}=9.01 ; \mathrm{p}<0.01)$, assimilation efficiency $(\mathrm{t}=5.16 ; \mathrm{p}<0.01)$, feeding $(\mathrm{t}=3.76 ; \mathrm{p}<0.05)$ and conversion $(\mathrm{t}=$ $2.58 ; \mathrm{p}<0.05)$ rates between the woodlice acclimatized at $14^{\circ}$ and $21^{\circ} \mathrm{C}$. Better feeding of P. granatum leaf by these animals was observed at $21^{\circ} \mathrm{C}$, but better assimilation efficiency at $14{ }^{\circ} \mathrm{C}$. Only $3.21 \%$ assimilated food at $14^{\circ} \mathrm{C}$ and $6.30 \%$ at $21{ }^{\circ} \mathrm{C}$ were converted into the production of new tissues. The food consumption of $A$. officinalis at $14^{\circ}$ and $21^{\circ} \mathrm{C}$ was $2.05 \%$ and $3.79 \%$ body mass/day respectively. The effect of temperature on the activity of $A$. officinalis in the field is discussed.

KEYWORDS: Armadillo officinalis; Punica granatum; transpiration; body mass; feeding and assimilation.

\section{Introduction}

$\mathbf{T}$ The coastal region of Benghazi (20 $\left.0^{\circ} 10^{\prime} \mathrm{N}, 20^{\circ} \quad 06^{\prime} \mathrm{E}\right)$, Libya, like other Mediterranean coasts (Kheirallah, 1980; Warburg et al. 1984) is colonized by the pillbug, Armadillo officinalis Dumeril. Casual collections showed that these woodlice occurred in large numbers in shady places where the soil moisture was moderate. Detailed studies were conducted by us before in Benghazi on the transpiration, behavior, growth and feeding habits (Nair et al. 1989), conversion of leaf litter (Nair and Fadiel, 1991), relation of body dimensions and the soil factors influencing the abundance (Nair and Al-Jetlawi, 1993), breeding and population biology (Al-Jetlawi and Nair, 1994), thermobiology (Nair et al. 2001) and food preference and litter breakdown (Nair et al. 2002) of this woodlouse. The present study investigates the impact of temperature acclimatization $\left(14^{\circ} \mathrm{C}\right.$ and $\left.21^{\circ} \mathrm{C}\right)$ on the transpiration rate, increment in body mass, moisture, feeding and food conversion of A. officinalis fed on the dry leaves of Punica granatum (Pomegranate) for 15 days. Pomegranate trees are common in Benghazi and A. officinalis forms the major component of the decomposer fauna of the fallen litter from these trees.

\section{Materials and Methods}

A. officinalis having body mass ranging from 65 to $72 \mathrm{mg}$ were selected for the study. 10 pillbugs (5 males and 5 non-gravid females) each, after starving them for eight hours to evacuate their gut contents, were maintained at $14^{\circ} \mathrm{C}$ and $21^{\circ} \mathrm{C}$ in a Gallenkamp incubator. Each animal, after taking its initial body mass near to $0.01 \mathrm{mg}$ in a Sartorius balance, was kept in a glass petridish $(5 \mathrm{~cm}$ diameter, $2.5 \mathrm{~cm}$ height $)$ containing a layer of wet filter paper (62 $\pm 2 \%$ R.H.) at the bottom. $300 \mathrm{mg}$ of the dry leaf of Punica granatum macerated with water for 12 hours to make it soft, was provided as food. The experiment lasted for 15 days, after which the body mass of the animal was determined. The remaining leaf and the fecal matter ejected by the pillbug were collected, dried and weighed. After measuring the transpiration rates, they were kept at $60^{\circ} \mathrm{C}$ for four days, dried and weighed to determine the moisture content. The experiment was repeated again and there was not much variations in the values between the replications, so the data were combined and the mean values of 20 pillbugs at each temperature were taken.

To study the transpiration rates, the pillbugs were weighed individually to $0.01 \mathrm{mg}$ and exposed separately for one hour over calcium chloride at the same temperature $\left(14^{\circ}\right.$ or $\left.21^{\circ} \mathrm{C}\right)$ in which they were maintained previously for 15 days, before re-weighing. The results are expressed as water-loss in $\mathrm{mg} / \mathrm{cm}^{2} / \mathrm{h}$. The surface area of the animal was calculated from the formula $\mathrm{S}=\mathrm{kW}^{2 / 3}$, where $\mathrm{S}=$ surface area, $\mathrm{W}=$ initial weight of the animal, $\mathrm{k}=$ constant. A value of $\mathrm{k}=12$ was adopted as it has been 


\section{THERMAL EFFECTS ON A. OFFICINALIS}

used by Cloudsley-Thompson (1969) and Nair et al. (1989) for African woodlice, and Nair and Nair (1985) for Indian species. This value is also the mean calculated by Edney (1951) for British species.

Consumption of food (C) of A. officinalis exposed to $14^{\circ}$ and $21^{\circ} \mathrm{C}$ was estimated in terms of $\mathrm{mg}$ dry food consumed by it for 15 days, assimilation (A) was calculated by subtracting the amount of dry fecal matter $(\mathrm{Fe})$ ejected from the total food consumed $(\mathrm{C})$. The production rate $(\mathrm{P})$ (due entirely to the increase in live body mass ) was determined as the difference between the body mass of the animal at the beginning and at the end of the experimental period. Metabolism (R ) represents the difference between A and P. Assimilation efficiency (Ae) was calculated by expressing A as a percentage of C. Gross $(\mathrm{Ge})$ and net $(\mathrm{Ne})$ production efficiencies were estimated expressing $\mathrm{P}$ as a percentage of $\mathrm{C}$ and $\mathrm{A}$ separately. Rates of feeding (Fr), assimilation ( $\mathrm{Ar}$ ), conversion $(\mathrm{Cr})$ and metabolism $(\mathrm{Mr})$ were determined by dividing $\mathrm{C}, \mathrm{A}, \mathrm{P}$ and $\mathrm{R}$ by half the sum of initial and final weights of the animal and then by the duration of the exposure period and expressed in terms of $\mathrm{mg} / \mathrm{g}$ live wt/day.

t-tests (Grimm, 1993) were done to find out the significance or otherwise of the data.

\section{Results and Discussion}

Duke (1992) reported that the leaf of $P$. granatum contains betulic acid, ursolic acid, corelagin, strictinin, tannin, granatins, casuariin, D-mannitol, 2-0-galloylpunicalin, 2-(2-propenyl)-delta-piperideine, 1,2,3,4,6-penta-0-galloyl-beta-D-glucose and 1.2.4.6-tetra-0-galloyl-beta-D-glucose. Our observations in the field revealed that the leaf of $P$, granatum is a preferred food for $A$. officinalis in the field, which was later confirmed through the laboratory studies on the food preference shown by them. Also, higher breakdown of the dry leaf of $P$. granatum by these animals was observed in the field when compared with the breakdown of the dry leaf of Citrus limonia (lemon) (Nair et al. 2002).

Table 1. Temperature acclimatization $\left(14^{\circ} \mathrm{C}\right.$ and $\left.21^{\circ} \mathrm{C}\right)$ for 15 days on the increment in body mass, transpiration rate, moisture, feeding and food conversion (Mean \pm SE) of $A$ officinalis fed on Punica granatum dry leaf as food, t-values and their levels of significance. Total number of woodlice kept at each temperature: 20

\begin{tabular}{|c|c|c|c|c|c|}
\hline \multirow[t]{2}{*}{ SI.No } & \multirow[t]{2}{*}{ Factors } & \multicolumn{2}{|c|}{$\begin{array}{l}\text { Animals exposed to the } \\
\text { temperatures of }\end{array}$} & \multirow[t]{2}{*}{$\mathrm{t}$} & \multirow[t]{2}{*}{$\mathrm{p}$} \\
\hline & & $14{ }^{\circ} \mathrm{C}$ & $21^{\circ} \mathrm{C}$ & & \\
\hline 1 & Increment in body mass (mg) & $0.97 \pm 0.33$ & $1.39 \pm 0.21$ & 1.09 & 1. $>0.05$ \\
\hline 2 & Transpiration rate $\left(\mathrm{mg} / \mathrm{cm}^{2} / \mathrm{h}\right)$ & $0.71 \pm 0.01$ & $1.01 \pm 0.03$ & 9.53 & $2 .<0.01$ \\
\hline 3 & Moisture (\%) & $52.20 \pm 0.18$ & $49.71 \pm 0.14$ & 9.01 & 3. $<0.01$ \\
\hline 4 & Assimilation efficiency (\%) & $81.16 \pm 3.21$ & $62.51 \pm 1.67$ & 5.16 & 4. $<0.05$ \\
\hline 5 & $\begin{array}{l}\text { Gross production } \\
\text { efficiency }(\%)\end{array}$ & $3.06 \pm 1.13$ & $3.87 \pm 0.54$ & 0.65 & 5. $>0.05$ \\
\hline 6 & Net production efficiency (\%) & $3.94 \pm 1.34$ & $6.11 \pm 0.82$ & 1.38 & $6 .>0.05$ \\
\hline 7 & Feeding rate (mg/g live wt/day) & $23.57 \pm 2.02$ & $38.22 \pm 3.33$ & 3.76 & 7. $<0.05$ \\
\hline 8 & $\begin{array}{l}\text { Assimilation rate }(\mathrm{mg} / \mathrm{g} \text { live } \\
\mathrm{wt} / \text { day) }\end{array}$ & $19.29 \pm 1.97$ & $23.66 \pm 1.83$ & 1.63 & 8. $>0.05$ \\
\hline 9 & $\begin{array}{l}\text { Conversion rate (mg/g live } \\
\text { wt/day) }\end{array}$ & $0.62 \pm 0.20$ & $1.49 \pm 0.27$ & 2.58 & 9. $<0.05$ \\
\hline 10 & $\begin{array}{l}\text { Metabolic rate (mg/g live } \\
\mathrm{wt} / \text { day) }\end{array}$ & $18.67 \pm 2.06$ & $22.17 \pm 1.65$ & 1.33 & 10. $>0.05$ \\
\hline
\end{tabular}


Table 1 shows the increment in body mass; transpiration rate; moisture; assimilation efficiency; gross and net production efficiencies; feeding, assimilation, conversion and metabolic rates of $\mathrm{A}$. officinalis at $14^{\circ}$ and $21^{\circ} \mathrm{C}$ for 15 days fed on the dry leaf of $P$. granatum, the t-values and their levels of significance. There was an average increase of $0.97 \mathrm{mg}$ in body mass of $A$. officinalis at $14^{\circ} \mathrm{C}$ which increased further to $1.39 \mathrm{mg}$ in those at $21^{\circ} \mathrm{C}$, even though the difference in increment in body mass between acclimatized temperatures was insignificant $(\mathrm{t}=1.09 ; \mathrm{p}>0.05)$.

The transpiration rate of $14^{\circ} \mathrm{C}$ acclimatized A. officinalis was $0.71 \mathrm{mg} / \mathrm{cm}^{2} / \mathrm{h}$, which increased significantly $(\mathrm{t}=9.53 ; \mathrm{p}<0.01)$ to $1.01 \mathrm{mg} / \mathrm{cm}^{2} / \mathrm{h}$ in those at $21^{\circ} \mathrm{C}$. The cuticle of land isopod is more permeable than that of insect (Wallwork, 1970) and it was previously believed that an oriented layer of lipid molecule, which functions as a water-proofing mechanism is lacking from isopods (Beament, 1961). Later, however, Warburg (1965) and Edney (1968) suggested that some type of water-proofing mechanism may be present in some species. Measurement of transpiration rates of several species of woodlice at various temperatures demonstrated a sharp increase at higher temperatures suggesting that the ability of waterproofing barrier is reduced at high temperatures (Cloudsley-Thompson, 1977; Nair and Nair, 1985). This phenomenon might not have taken place in the present study since the higher temperature of $21^{\circ} \mathrm{C}$ was well within their tolerance limits and temperature acclimatization might be the sole criterion for their differences in transpiration rates. Our previous studies (Nair et al., 1989, 2001) on A. officinalis revealed that the exponential regression models fitted on transpiration in relation to temperatures were good and acclimatization of these pillbugs to different temperatures for a week had marked effects on their transpiration and behavior, when later exposed to rising temperatures.

A significant difference $(\mathrm{t}=9.01 ; \mathrm{p}<0.01)$ in moisture content was discernible in A. officinalis acclimatized between $14^{\circ} \mathrm{C}(52.20 \%)$ and $21^{\circ} \mathrm{C}(49.71 \%)$. Significantly higher assimilation efficiency $(\mathrm{t}$ $=5.16 ; \mathrm{p}<0.01)$ was recorded in those acclimatized at $14^{\circ} \mathrm{C}(81.16 \%)$ than those at $21^{\circ} \mathrm{C}(62.51 \%)$. The values of gross and net production efficiencies, and also of feeding, assimilation, conversion and metabolic rates were higher in A. officinalis exposed at $21^{\circ} \mathrm{C}$ when compared with the values recorded at $14^{\circ} \mathrm{C}$. However, significant differences existed only between their feeding $(\mathrm{t}=3.76 ; \mathrm{p}<0.05)$ and conversion $(\mathrm{t}=2.58 ; \mathrm{p}<0.05)$ rates.

Warburg (1987) opined that isopods in general seem to be efficient digesters but somewhat inefficient assimilators and that food consumption varies with species. In the present study an inverse relationship was observed in A. officinalis on its feeding rate and efficiency of assimilation of the leaves of $P$. granatum. Better feeding was discernible in those kept at $21^{\circ} \mathrm{C}$, but better assimilation efficiency was observed in those at $14^{\circ} \mathrm{C}$. Only a small percentage of the assimilated food $\left(3.21 \%\right.$ at $14^{\circ} \mathrm{C}$ and $6.30 \%$ at $\left.21^{\circ} \mathrm{C}\right)$ was converted into the production of new tissues. The food consumption of A. officinalis fed on P. granatum was $2.05 \%$ body mass/day at $14^{\circ} \mathrm{C}$ and $3.79 \%$ body mass/day at $21^{\circ} \mathrm{C}$. These values were lower than those reported for Porcellio scaber $\left(2.59 \%\right.$ body mass/day at $14^{\circ} \mathrm{C} ; 4.19 \%$ body mass/day at $21^{\circ} \mathrm{C}$ ), another woodlouse which co-exists with $A$. officinalis in the field and were given $P$. granatum as food for 15 days (unpublished data).

In conclusion, temperature acclimatization has a significant impact on the transpiration rate, moisture, assimilation efficiency, feeding and conversion rates of A. officinalis fed on P. granatum, but not so on their increment in body mass, gross and net production efficiencies, assimilation and metabolic rates. The effects of temperature on the activity of these pillbugs were confirmed in the field where they were found in large numbers crawling over the soil surface and actively feeding on the leaf litter when the surface temperature ranged between 18 and $29^{\circ} \mathrm{C}$, even though activities were restricted to shady places. It was evident that a restricted grade of temperature gradient was essential for normal activity and feeding. Except for short summer months of August/September, the temperature range of the habitats of these animals was well within their tolerance limits. 


\section{References}

AL-JETLAWI, A.A. and NAIR, G.A. 1994. Breeding and population biology of Armadillo officinalis (sopoda: Oniscidea) in Benghazi,Libya. J. Arid Envts., 27: 241-255.

BEAMENT, J.W.L. 1961. The water relations of the insect cuticle. Biol. Rev., 36: 281-320.

CLOUDSLEY-THOMPSON, J.L. 1969. Acclimation, water and temperature relations of the woodlouse Metoponorthus pruinosus and Periscyphis jannonei in the Sudan. J. Zool., 158: 267-276.

CLOUDSLEY-THOMPSON, J.L. 1977. The Water and Temperature Relations of Woodlice. Meadowfield Press, Durham

DUKE, J.A. 1992. Handbook of Phytochemical Constituents of GRAS Herbs and other Economic Plants. CRC Press, Ann Arbor, U.S.A.

EDNEY, E.B. 1951. The evaporation of water from the woodlice and the millipede Glomeris. J. Exp. Biol., 28: $91-115$.

EDNEY, E.B. 1968. Transition from water to land in isopod crustaceans. Am. Zoologist, 8: 309-326.

GRIMM, L.G. 1993. Statistical Applications for the Behavioral Sciences .John Wiley \& Sons, New York.

KHEIRALLAH, A.M. 1980. Aspects of the distribution and community structure of isopods in the Mediterranean coastal deserts of Egypt. J. Arid Envts., 3: 69-74.

NAIR, G.A. and AL-JETLAWI, A.A. 1993. Observations on the relation of body dimensions and the ecological factors of the soil influencing the abundance of the pillbug Armadillo officinalis Dumeril 1816 (Isopoda, Oniscidea) in Benghazi, Libya. J. Animal Morph. Physiol., 40: 61-71.

NAIR, G.A., BENNOUR, S.A., EL-AMMARI, N.E. and CHOWDHURY, K. 2002. Food preference and breakdown of Citrus limonia and Punica granatum dry leaves by Armadillo officinalis Dumeril, 1816 and Porcellio scaber Latreille, 1804 (Isopoda, Oniscidea) in Benghazi, Libya. Ecol. Env. \& Consv., 8(3): 223-226.

NAIR, G. A. and FADIEL, M.M. 1991. The feeding and conversion of leaf litter by the pillbug Armadillo officinalis (Isopoda, Oniscidea). Arid Soil Res. \& Rehab., 5:167-174.

NAIR, G.A., FADIEL, M.M. and MOHAMED, A.I. 1989. Effects of temperature on transpiration, behavior, growth and feeding habits of Armadillo officinalis (Isopoda, Oniscidea) in Benghazi, Libya. J. Arid. Envts., 17: 49-55.

NAIR, G.A., MOHAMED, A.I. and BHUYAN, K.C. 2001. Thermobiology of Armadillo officinalis and Hemilepistus reaumuri (Isopoda: Oniscidea) in Benghazi, Libya. In: Ecology of Desert Environments. ed. Ishwar Prakash, Scientific Publishers, Jodhpur, India.

NAIR, G.A. and NAIR, N.B. 1985. Transpiration rates and acclimatigation to water and temperature of the tropical woodlice Porcellionides puinosus Brandt and Porcellio laevis Latreille. Proc. Indian Acad. Sci., 94(5): 469-474.

WALLWORK, J.A. 1970. Ecology of Soil Animals. McGraw Hill, London.

WARBURG, M.R. 1965. Water relations and internal body temperature of isopods from mesic to xeric habitats. Physiol. Zool., 38: 99-109.

WARBURG, M.R. 1987. Isopods and their terrestrial environments. Adv. Ecol. Res., 17: 187-242.

WARBURG, M.R., LINSERMAIR, K.E. and BERKOVITZ, K. 1984. The effect of climate on the distribution and abundance of isopods. Symp. Zool. Soc. London, 53: 339-367.

Received 4 June 2003

Accepted 28 March 2004 